\title{
ECO-ORIENTED ARCHITECTURE AS A MEANS OF CREATING A SUSTAINABLE URBAN ENVIRONMENT
}

Scientific paper / Znanstveni rad

\section{Maksym Votinov}

(Received: 06 February 2019; accepted: 27 May 2019)

Department of the basics of architectural design, O.M. Beketov National University of Urban Economy in Kharkiv, Associate Professor

Corresponding author: 0.l-y.a@mail.ru

\section{Olga Smirnova}

Department of Architecture of Buildings and Structures and Design of Architectural Environment, O.M. Beketov National University of Urban Economy in Kharkiv, Associate Professor

\begin{abstract}
Eco-oriented architecture is considered the basis for the humanization of modern. An analysis of world experience is carried out and the basic features of humanization of the urban environment are identified, considering the system-ecological approach. The eco-oriented architecture is considered a means of creating a sustainable urban environment. The features of the creation of objects in eco-oriented architecture in the twentyfirst century are identified. The techniques for creating eco-oriented architectural objects in the urban environment are identified, and their sustainable development is considered. In addition, the innovative concepts and future trends in the creation of eco-oriented architectural objects are identified.
\end{abstract}

Keywords: eco-oriented architecture; sustainable development; urban environment

\section{EKOLOŠKI USMJERENA ARHITEKTURA KAO TEMELJ POSTIZANJA ODRŽIVOG URBANOG OKOLIŠA}

Sažetak: Ekološki usmjerena arhitektura smatra se temeljem humanizacije moderne arhitekture. Provedena je analiza svjetskih iskustava i definirane su osnovne karakteristike humanizacije urbanog okruženja, uzimajući u obzir sustavan ekološki pristup. Ekološki usmjerena arhitektura smatra se sredstvom stvaranja održivog urbanog okruženja. Istaknute su karakteristike i tehnologije stvaranja zgrada ekološki usmjerene arhitekture 21. stoljeća, uzevši u obzir njihov održivi razvoj. Dodatno, identificirani su inovativni koncepti i budući trendovi kreiranja ekološki usmjerenih zgrada.

Ključne riječi: ekološka arhitektura; održivi razvoj; urbano okruženje

Votinov, M, Smirnova, 0 


\section{INTRODUCTION}

In the 21st century, rapid, high-speed urbanization is a global problem. The development of large cities and megalopolises has led to the emergence of new sources of environmental transformation and pollution, as well as changes in urban space. The growth of the urban population and the consolidation of urban development attribute particular importance to the problem of ecologization of the living environment. Urban development causes a reduction in the amount of clean air, water, and green spaces and deteriorates the noise, insolation, and aeration regime of the area. One of the causes of environmental degradation is the slow ecologization of the life and consciousness of modern persons. The urban environment is largely characterized by a chaotic state of construction, an increase in population, uncomfortable environmental indicators (noise, air pollution, etc.), negative characteristics of transportation and pedestrian infrastructure, crowding out of the environment by city elements, and the need for renovation of industrial, residential, and recreational infrastructures. Nature and even humans are beginning to be forced out of the city by technology, communications, equipment, and buildings. The amount of environmentally oriented space is decreasing. It is necessary to create a fundamentally new architecture for buildings and structures to solve this problem and implement radical changes in the architectural and urban planning formation, and to increase the ecological and aesthetic potential of the modern urban environment. Research on ecologization methods for urban spaces through the creation of eco-oriented buildings is an essential aspect of improving the quality of the human environment. This leads to a search for new forms of buildings through the creation of buildings characterized by synergistic space-planning methods, high-quality urban-planning methods, and the maximum socioeconomic efficiency of land use.

\section{ANALYSIS OF THE LITERATURE DATA AND THE FORMULATION OF THE PROBLEM}

Analysis of the literature has shown that the issues of integrated interrelations between the natural and architectural environment of the city are touched upon in the works of various authors, and various aspects of the formation of the urban environment are considered:

1. Historical development of architectural objects with the use of natural elements was reviewed in the scientific research of N. Ya. Krizhanovskaya [1], I. A. Dobritsina, H. L. Titova, J. Wines [2], P. Jodidio [3], and P. Gossel [4].

2. Typological formation of the architectural environment with elements of landscaping was reviewed in the scientific research of K. Alexander, N. K. Chkhartishvili, E. Yu. Kupffer, C. Broto [5], D. Browning [6], and M. Zeiger [7].

3. Integration of the architectural and natural environments and landscaping issues to improve the ecological and aesthetic characteristics of the urban environment were reviewed in the scientific research of $N$. Ya. Krizhanovskaya [8], S. S. Yankovich, V. A. Gorokhova, V. P. Vergunov [9], K. Lynch, D. Symonds, D. V. Zemov, and G. O. Belyavsky.

4. Energy-saving and ecologization techniques for the urban environment were reviewed in the scientific research of I. E. Grabar, S. Ya. Zabello, P. A. Rappoport, E. A. Ashepkova, A. Sakharova, I. I. Anisimova, E. V. Sarnatsky, S. K. Sarkisov, D. O. Mazharova, A. P. Platonov, A. I. Prokhorenko, V. A. Fedorov, and L. I. Tsvetkova, T. Yigitcanlar [10].

5. Various aspects of the humanization of the architectural environment as a whole were reviewed in the scientific research of A. E. Gutnov, I. V. Lezhava, K. Lynch, S. Matreninskiy [11], et al.

6. The principles of planning and building cities were reviewed in the scientific research of A. V. Ikonnikov, T. P. Kuznetsova, B. M. Merzhanov, S. Matreninskiy [11]; socio-psychological research of the urban environment was reviewed in scientific research of G. M. Andreeva, S. E. Gabudzina.

Research of scientific developments shows that a holistic methodological approach to the problem of humanization and ecologization of the urban environment has not yet been developed, but positive experience in solving certain aspects of this problem can be found in theoretical and project development [12-16]. 


\section{PURPOSE AND OBJECTIVES OF THE STUDY}

The purpose of this research is to provide a detailed overview of the characteristics of eco-oriented architecture, as well as the design principles and concepts according to which this type of architecture is designed.

To achieve this goal, the following research objectives were identified:

1. Based on the analysis of real-world experience, to identify the features of the eco-oriented architectural objects' formation in the urban environment.

2. To identify innovative concepts and perspective trends in the formation of eco-oriented architectural objects in the urban environment, considering sustainable development.

\section{RESEARCH METHODOLOGY AND APPROACHES TO THE OPTIMIZATION AND ECOLOGIZATION OF THE URBAN DEVELOPMENT INFRASTRUCTURE}

The research methods used by the authors to solve the formulated problem are based on knowledge of the methodological and general theoretical characteristics of the construction of foundational scientific research. To form the research strategy, a number of positions of the system-ecological, synergistic, and environmental approaches were used. This approach to solving town-planning problems assumes various objects of townplanning activity as elements of the human environment. It is aimed at improving the formation of the urban environment, preserving the historical basis, developing and enriching its ecological and aesthetic potential, and forming an optimal solution to contemporary problems in the environment of life. Such an approach to designing objects of the urban environment is necessary in connection with anthropogenic pollution of the biosphere, which, with the consumption of natural resources, is becoming increasingly dangerous. It is a priority in solving the environmental problem. This approach contributes to deepening the environmental and spatial views in design and includes the concepts of a healthy environment.

The following methods were used to solve the tasks set in this research:

- The method of historical and genetic analysis was used to identify the evolutionary development of eco-oriented architectural objects and to identify persistent trends for their further development.

- The method of factor and comparative analysis was used to identify patterns in the formation of ecooriented architectural objects in the urban environment.

- The method of comparative analysis of design and graphic materials (general plans and plans for eco-oriented buildings) was used to identify the planning structure, compare the results, and identify the specifics of the formation of eco-oriented architectural objects in the urban environment.

- Deductive and inductive methods were used for the generalization and comprehensive systematization of the data obtained in general and in detail.

- The structural-system method was used to build a model of the perspective formation of eco-oriented architectural objects in an urban environment.

- The method of visual observation and photographing territories with objects of eco-oriented architecture was used to identify the compositional features of the formation of these objects.

\section{SPECIFICS OF THE FORMATION OF ECO-ORIENTED ARCHITECTURE IN THE URBAN ENVIRONMENT}

\subsection{Stages of development eco-oriented architecture}

Eco-oriented architectural objects represent architectural formations that interact harmoniously with the natural environment, aimed at creating an individual comfort microclimate in the interior and exterior spaces and improving their environmental and aesthetic characteristics. Research on the historical experience of the formation of ecooriented architecture objects revealed the six main stages of their development, which characterize their organizational features: antique, medieval, industrial revolution, organic, innovative, and modern. Various stylistic patterns of the formation of objects in eco-oriented architecture are manifested in the process of historical development. The styles of the architectural environment and landscape of modern eco-oriented architecture 
determines the artistic image of both the separate building and the adjacent land plot. It may have a historical or modern character. The specific stylistic approach to achieve the architectural expressiveness of eco-oriented architecture objects is achieved by imitating the features of the surrounding natural landscape (bionic architectural volumes or landscape forms) due to the desire to create an architectural volume in contrast to the environment (traditional or formal image of the building). It was established that in the early period (up to the 15th century), the aesthetic requirements for the organization of eco-oriented architecture objects prevailed; at the intermediate stages in the revolutionary period (16th to early 20th centuries), their formation took place with the use of new (for the time) construction technologies; and in the final stages of the sustainable development period, from the end of the 20th century, priority was given to eco-design with the integration of buildings and the landscape. Based on the analysis, it was established that the main factors influencing the formation of eco-oriented architecture objects at all stages of their development are climatic, landscape/ecological, aesthetic/town-planning, sociodemographic, national, engineering, technical, and technical/economic. The formation of modern architectural objects should be based on an environmental approach in the presence of specially designed, efficient, and safe engineering and structural systems, using renewable energy sources (geological, hydrological, and biological), local generation, and techniques for directly linking interior and exterior spaces with varying degrees of landscaping:

- Transformation of the volume (based on defragmentation, integration, or duplication and displacement of elements, and additional types of transformation);

- A combination of geometric volumes (the creation of a new combined volume);

- Volume, integration of one volume into another, connection with additional volumes;

- Imitation of anthropogenic and natural forms (complete or abstract imitation).

It should be noted that the use of the identified techniques in the formation of buildings significantly increases their level of comfort.

\subsection{Main principles of the eco-oriented architecture formation}

The main principles of the formation of modern eco-oriented architecture objects were identified:

- The principle of ergonomics is aimed at creating a commensurate volume of a building with a flexible planning structure of interior and exterior spaces, comfortable functional contents, and an individual microclimate to ensure the psychophysical health of the person.

- The principle of natural integration provides for the integration of the volume of the building with the surrounding landscape using a specific architectural planning and design techniques; natural materials; and the inclusion of green recreational spaces in the building structure.

- The principle of structural formation is aimed at creating an economical volume of a building with the potential for implementation of its adaptation, considering the functional purpose and needs of people.

- The principle of ecological comfort is aimed at the creation of energy-saving buildings placed at various levels relative to the landscape surfaces with a system of stable autonomous functioning and regulation of the microclimatic indicators.

- The principle of aesthetic uniqueness is aimed at the creation of an individual expressive artistic image of the building using new technologies, modern materials, original color, and various methods of incorporating natural elements into architecture.

Accounting for these principles in the design of eco-oriented architecture objects in an urban environment will allow the creation of full-fledged, self-sufficient structures. The creation of such objects is especially important from the perspective of innovative development of the urban environment in the future.

In particular, the interest in the design and forecasting of structures in the natural environment based on futurological concepts has increased.

\subsection{Characteristics of eco-oriented architecture}

The third millennium is the epoch of ecological design integrating traditional and innovative approaches, and is the period of the formation of futurological architecture aimed at solving the actual problems in an idealized and conceptual form. Innovation activity is characterized by constant high-quality improvement of the living environment, 
promotion (introduction) of modern building technologies and designs, new types of building materials and services, and automatic funds into the urban infrastructure based on futurological concepts. It is also characterized by the use of techniques aimed at maintaining the emotional and psychological microclimate in the urban environment, and the achievement of an organic relationship between man, architecture, and the natural environment. The most active part of society comprises innovators (scientists, specialists, and inventors), creating new technology, meeting modern requirements, and progressing concepts of sustainable development of the urban environment. Currently, they provide a wide range of futurological design solutions working in the following areas of architectural activity:

Engineering design is the field of architecture and design, a special part of industrial design associated with the formation of architectural objects and their engineering systems: the use of simple geometric forms and logic of formal composition in the construction of architectural objects; rational structure; and identification of functions in the structure of the form and tectonics of the building $[10,13]$.

Art design is a trend in modern architecture and design, characterized by the creation of objects with a pronounced priority of aesthetic principles, aimed at creating an impression derived from the visual perception of architectural objects. The active use of emotional and imaginative content, mastered in the process of compositional formation of architectural objects, is built based on both abstract and real images.

Futuro-design is the field of architecture and design with experimental creative activity, which determines the main ways of changing the visual image and building systems, and the prospect for the development of its subject-spatial environment. Operating with scientific methods uses formal composition, reflecting the emotional content and artistic/figurative modeling. A conceptual direction is acquired as a result of the transition from forecasting the shape of an architectural object to thinking about its scenarios [10].

Conceptual design is a design based on the developed concept, which includes analytical schemes using holistic universal constructions. The developed conceptual project represents a visual, virtual, and verbal model of an artistic/figurative object using formal composition and artistic/psychological modeling [11]. These areas of architectural activity are aimed at the study, modeling, and implementation of futurological concepts that reveal the most perspective trends, the embodiment of which, in modern conditions, can provide positive dynamics and sustainable development of the architectural environment in the natural environment. Therefore, a number of difficult questions in the construction of modern architectural objects can be answered by creating a competent project in which the level of comfort is determined by establishing the ecotype of the architectural and landscape environment of the building (in accordance with the values prevailing within).

In the structure of the building, the following positions can be represented: environmental protection of the building, characterized by the predominance of natural forms, stable equilibrium, and prioritization of living with nature; ecocentric environment, dynamic equilibrium, the harmonious interaction of man and nature, ecoconservation, characteristics of the traditional suburban, and other favorable environments. This can be an anthropocentric environment, the predominance of man and environment of his life activity, anthro-preservation, and characteristics of the urban environment; the automated environment of the building, dominated by technical spaces, automated equipment, communications, as a rule, in the interior of the building, and environmental protection in the exterior. The cyber environment of eco-oriented architecture is characterized by the presence of spaces created by technical and artificial means. The implementation of processes related to human activity is carried out by means of intellectual architecture. Thus, it is necessary to highlight several futurological concepts of the formation of objects of eco-oriented architecture.

\subsection{Concepts for the design of eco-oriented architecture}

The first concept is technological. It is the use of innovative buildings and structures to enrich the living environment with multimedia technologies, creation of a dynamic structure of architectural objects with the possibility of replacing their individual functional elements to increase the level of comfort in an architectural environment, and the active modeling of architectural forms (projects within the framework of the concepts of metabolism, metamorphism, water, the ground, and other buildings). Modern modification of artificial structures, characterized by intent and demonstration, where engineering systems and other technical equipment overcome the functional need and determine the individual image of the building, can seem grotesque (taken out ladders, engineering systems). This is based on the imitation of living nature, developed over time. The development or growth is similar to that of a living organism (the structure of building with variable modular elements, "growing" composition); in contrast to organic architecture, buildings are limited to imitating the characteristics of the formation Votinov, M, Smirnova, 0 
of natural objects. They are characterized by incompleteness, understatement, and openness of the structure of the building for communication with the surrounding changeable natural environment. One of the examples illustrating this concept is a water feature of eco-oriented architecture. This object is intended for a temporary or permanent residence, and its spatial planning and constructive solution is adapted to certain natural, in particular hydrological, conditions of the area to ensure a high level of comfort and safety for human life. The search for an alternative solution to such an object of eco-oriented architecture suggests several options for its location: on coastal areas (near a reservoir), on the surface of the water, or under the water. Based on this, such eco-oriented architectural objects may be characterized by the presence of a static or dynamic floating base. In Asian countries, such facilities are located on both natural and artificial reservoirs. In Thailand, these buildings are constructed on stilts, and in China, eco-oriented architectural objects are buildings like boats (sampans).

The modern construction of the building is the houseboat, floating across the expanse of the sea. One such project for very wealthy people is an ecological green island called "Orsos Island." It is a house on a floating platform that combines all the advantages of high-comfort floating facilities and elite housing (Figure 1).

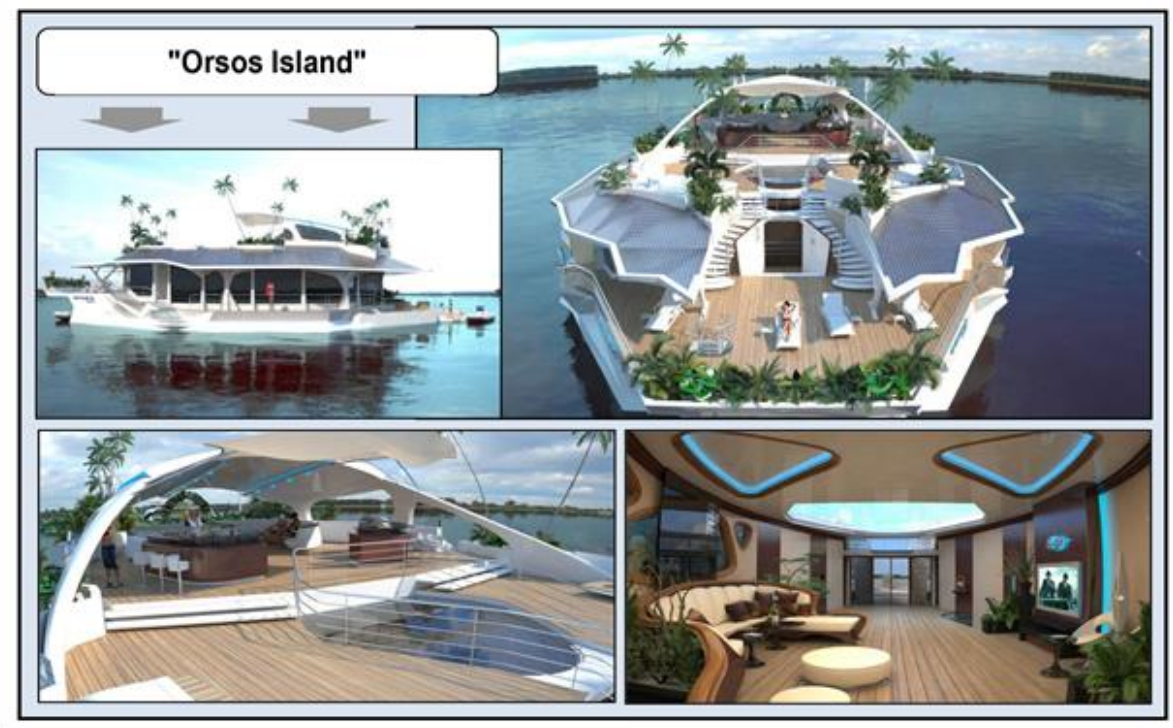

Figure 1 "Orsos Island" [17]

The house located on the surface of the water can be as static or dynamic as needed by the individual. The island, designed for twelve tenants and four crew members, has a size of $20 \times 37 \mathrm{~m}^{2}$ (the living area is more than $1000 \mathrm{~m}^{2}$ ) [15]. Its planning structure includes all the necessary facilities. The house/island is a completely autonomous system: the use of solar panels, wind generators, two diesel engines, an intelligent computer system, and other equipment helps ensure comfortable recreation.

The second concept is environmental. The priority of this concept is to create and maintain a balance between architecture and the natural environment ("bio-tech" and "eco-tech"). These trends in architecture are aimed at communication in technical building and the achievements of organic architecture and the integration of nature and the building. These buildings are often likened to fantastic living beings (surrealistic sculptural nature of a building). The use of eco-oriented architecture solves the problem of environmental savings throughout the entire life cycle of a building (from the design decision to utilization, with the calculation of all the energy expended in the process of its design, existence, and reorganization).

Villa "Amanzy" is an example of an object of eco-oriented architecture. It was built in the mountains on the edge of a cliff (Figure 2). The total land area is $2644 \mathrm{~m}^{2}$ and the residential building is $800 \mathrm{~m}^{2}$. 


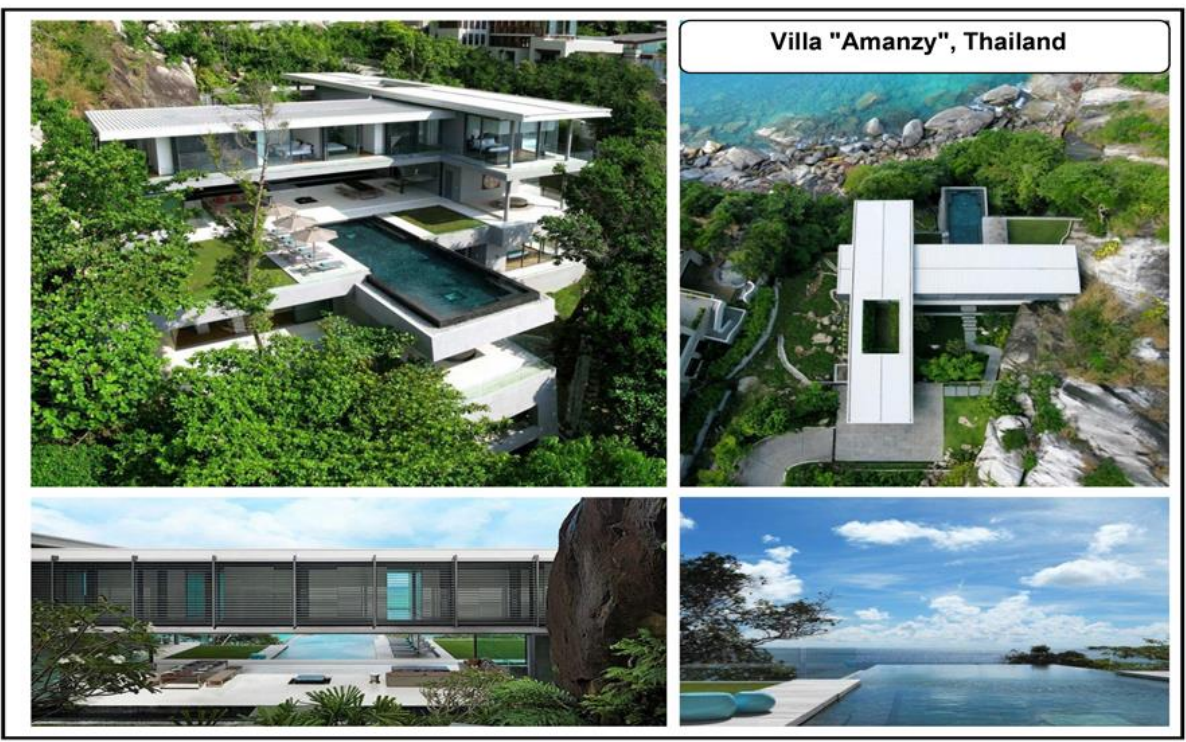

Figure 2 Villa "Amanzy," Thailand [18]

The focus is on the natural component of the construction site. The mult-level solution of the building ensures maximum interaction with the surrounding landscape. The upper level of the house is surrounded by tropical vegetation; water and rocks are below the main natural components. The house is closely adjoined to the rock and has several rooms built between the rocky ledges $[19,20]$. The combination of technology, modern design, and the beauty of the surrounding nature provided integration between the building and nature.

Among the many approaches aimed at combining exterior and interior spaces, the theme of ecological integration, such as that in "Meera House," is particularly interesting (Figure 3). Owing to the small size of the island, the main task in creating the project was to maximize the use of the site for the construction of a spacious house while preserving the privacy of the owners and the proximity of nearby buildings [21].

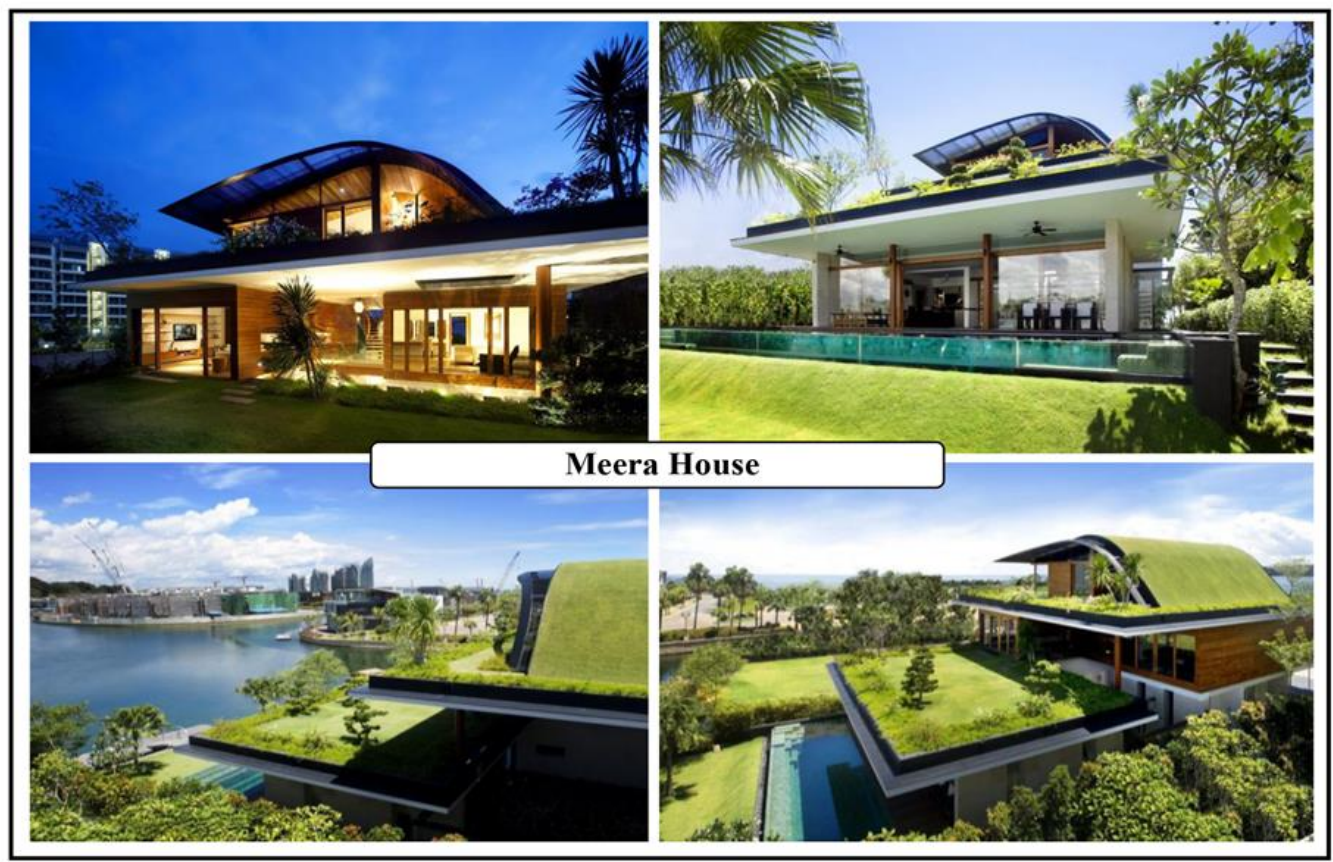

Figure 3 "Meera House" [22]

Votinov, M, Smirnova, O 
The third concept is technological with an environmental focus. This concept seeks new forms of architectural spaces using innovative engineering technologies, allowing resources to be saved and using renewable clean energy sources. This concept is illustrated by the projects of two modern villas, "Rock" and "Shell" (arch. Art. Zaha Hadid). They are parts of the future complex, which will be located in the natural environment on a high plateau (300-400 m above sea level), to the north of the ancient Croatia. This location will provide beautiful views of the picturesque panorama of the Mediterranean Sea and the mountainous landscapes of Croatia. One of the features of this concept is also a transformation, determined by the change in the functions of objects in ecooriented architecture and the connection of its internal space with the external environment [15].

Eco-oriented architecture objects are transformable within a certain period to increase the level of insolation, aeration, and communication with the external environment, changing the degree of isolation of the internal space via the mobile elements of coatings and enclosing structures. The frequency of changing functions and the multipurpose use of the internal space of the building leaves its form unchanged, varying the planning, technical, and aesthetic characteristics of the space. Often eco-oriented architecture objects are formed with long-term adaptation in mind, without the possibility of returning to the initial state. Structures are designed with a planned reserve for their dynamic development in a changing environment. The adaptability of functional, technical, and aesthetic resources of the building allows its structure to be transformed during the entire period of operation, adding additional blocks, tiers, and modules to the primary volume. A combination of forms creates new original schemes of planning and volume-spatial structures of objects in eco-oriented architecture.

The fourth concept is anthropocentric. It is the concept that prioritizes striving for human domination:

creating an ideal model of the building of the future and changing the nature of the owner's life (projects within the framework of the mobile building concept). The main advantages of this direction are the multiple relocations of the architectural objects with minimal time spent on assembly and disassembly in remote and inaccessible areas. The adaptive capacity of the buildings allows them to be placed in areas with harsh climatic conditions, where infrastructure, resources, and a base for capital construction are lacking. The mobility of eco-oriented architecture objects allows them to exist and function in space without damaging the natural environment in which they are located. Buildings are actively used, thereby solving many problems of modern architecture via their transportability and adaptability (in particular, the construction of economical housing based on mobile units).

The fifth concept is information. It involves seeking to facilitate the life processes of the people, streamlining the structure of the building, and achieving energy efficiency in the building through the introduction of innovative automated technologies into its infrastructure (projects implemented under the concept of "smart building"). The direction combines the characteristics of dynamic architecture, an example of the synthesis of the architecture of a building with new achievements in science and technology. The structure of the building is based on innovative approaches to design based on detailed research of the environment; is capable of self-regulation, selfimprovement, and self-reproduction; and expresses the features and trends of the third millennium (achievements in cybernetics, bionics, laser optics, and other modern technologies) [15].

The rational combination of technology and modern design is based on two directions of this concept:

The concept of a "biological" building (Europe) operates in accordance with the biorhythms of the human body. It involves a constant exchange with the environment: reduction of pollutants, elimination of electromagnetic and ionizing radiation, air conditioning and ozonation, and the use of an intelligent life-support system. Placing a building is possible at the level of the earth's surface or at a certain height (on trees, rocks, and mountains), deep under water, with periodical landfall, and mobile buildings. These are completely autonomous systems; they are formed under the influence of modern trends and technologies that assume the further development of their image and infrastructure over time.

The concept of an automated intelligent architectural object-equipped with an integrated automated lifesupport system, and environmentally oriented-saves energy. There are two types. The first type involves managing objects and interacting with devices via the global Internet according to the required program, notification, and reporting for means of communication. The second type provides the ability to control the climate inside the building, lighting, and fire-extinguishing systems in the building and in the adjacent area by means of remote controls.

In the conclusion of the research, it should be noted that the presented futurological concepts of buildings illustrate the joint desire of architects, engineers, and designers to create flexible, mobile architectural structures that are adapted to the increased requirements of modern humans. The architectural and landscape organization

Votinov, M, Smirnova, 0 
of such innovative objects must comply with high rates of technical and environmental comfort, the level of which is determined by identifying the prevailing ecotype of space. The introduction of ecological bases and the use of scientific and technical developments in projects of eco-oriented architecture objects that generate new ideas will reveal the potential possibilities of modern architecture and open up great prospects for creating high-quality architectural objects. The considered futurological concepts of building enable distinguishing their main types: technological, environmental, technological with environmental orientation, anthropocentric, and informational concepts. These concepts reflect promising trends in the design of eco-oriented architecture objects. These include the consideration of the building as a dynamic system with varying parameters (transformation of structural elements and functional zones); use of various landscape surfaces (earth, water, etc.) for the placement and functioning of architectural objects; creation of self-sufficient engineering infrastructure of the building (automated and multimedia technologies, renewable energy sources); harmonization with the environment, removal of objects and factors that adversely affect the environmental and aesthetic component of the building; use of spatial engineering structures-the creation of a common structural system-for support (modular structure, etc.); and the search for new expressive architectural forms to create an individual artistic image of the building. Thus, the emergence of futurological projects of eco-oriented architecture, developing the ideas of mobility, growth, and adaptation to environmental conditions while creating an artificial environment, leads to the realization of a harmonious integration between architecture, humans, and the natural environment, based on humane strategies for the use of natural energy, eco-materials, and balanced building operation systems.

\subsection{Architectural activities and efficiency of creating eco-oriented architecture in the urban environment}

The increasing number of eco-oriented buildings is due to the nature of market relations, the

need for deep qualitative transformations of the living environment, the emergence of new technologies, and increased human demands on the surrounding architectural environment. The inherent properties of such buildings are their novelty and their economic and social expediency. They will be in demand in the future. It is necessary to identify the main criteria for the effectiveness of creating eco-oriented buildings in an urban environment, considering its sustainable development: social efficiency, environmental planning efficiency, engineering efficiency, economic efficiency, and integral efficiency. The effectiveness of the creation of such buildings, above all, characterizes their relevance to society.

The social efficiency of creating innovative buildings provides for the interest of the state and investors in the construction and integration of these objects into the urban environment, as evidenced by the presence of regulatory support for the design of such buildings and the increase in the level of scientific and technological development of society. Social efficiency is expressed by the positive experiences of the population following the implementation of innovative building projects: improving quality of life while increasing the volume of new facilities and the functions they provide; creating a comfortable human environment with primary consideration of its social (individual, family, and collective), anthropometric, and psychological needs and characteristics to achieve greater coherence and interaction between the human-architecture-natural environment system.

Ecological and urban-planning efficiency of eco-oriented buildings is quite high. Such buildings improve the temperature, humidity, and wind regimes, improve the insolation regime of the area, reduce pollutants, eliminate electromagnetic and ionizing radiation, provide air conditioning and ozonation, interconnect the natural and artificial environment, reduce greenhouse gas emissions, and reduce the anthropogenic impact on the environment, ensuring environmental security. The inclusion of eco-oriented buildings in the urban environment contributes to the preservation and maintenance of the existing natural elements of the urban environment (the creation of innovative buildings with the inclusion of gardens on artificial grounds to replace the lost fragments of the natural component of the city), strengthening of the existing natural elements of the urban environment (transformation of areas of the natural landscape by complicating the horizontal and vertical structures of green spaces in the created innovative architectural objects), and creation of new natural elements of the urban environment. Creating a unique architectural environment with the integration of natural components in the future will allow the building to preserve and dominate natural landforms with organic integration and dominance of buildings in the natural environment, as well as enabling the creation of artificial relief forms. These projects use eco-biomaterials and technologies that simplify and accelerate the construction process, reduce costs, and increase the energy efficiency of the object.

Votinov, M, Smirnova, 0 
Eco-oriented buildings contribute to the engineering and technical efficiency of the living environment through the introduction of the latest modern engineering and structural systems and automated intelligent technologies (achievements of cybernetics, bionics, laser optics, etc.) to enhance the utilitarian and aesthetic qualities of the object. Unique buildings improve the management processes of the architectural environment by a number of indicators-lighting, electrical equipment, fire extinguishing systems, video surveillance, automatic person identification, and other systems that detect violations in the operation of an object and in the adjacent territory-controlled via the Internet using remote controls and panels.

The economic efficiency of eco-oriented buildings solves the problem of saving financial and natural resources during the construction of objects from the beginning of their life cycle to complete harmless disposal with the calculation of all energy (territory, water, energy and atmosphere, materials and resources, internal quality of the environment, innovation). As a result, the most objective criterion for assessing the formation of eco-oriented buildings in an urban environment is the integral efficiency of the living environment, which provides for system interaction and consideration of all the criteria.

Thus, the concept of prospective development of the urban environment, considering the formation of ecooriented architecture, should be the result of an analysis of modern trends in their creation and should be formed based on new directions in construction and architecture, using modern design and engineering construction, energy-saving technologies and landscaping, and urban and light color design. However, the construction of ecooriented architectural objects in the urban environment is a technically sophisticated and financially expensive process at all stages of its creation and sustainable development in the future, especially with the changing needs of society.

\section{CONCLUSION}

As a result of the research, the following conclusions were formulated:

1. The features of the formation of eco-oriented architecture objects that reflect current trends in the design of the architectural environment in the 21st century are considered. One of them is an orientation towards sustainable development and an environmental approach (use of energy-saving techniques: solar-, geo-, wind-, hydro-, and bio-functioning systems). It has been established that such an architectural environment should be an environmentally oriented system. The main techniques of designing eco-oriented architecture objects in the $21 \mathrm{st}$ century, aimed at creating a holistic architectural and artistic image using transformation, combinations of geometric volumes, and imitation of anthropogenic and natural forms, are defined.

2. The main innovative concepts for designing eco-oriented architecture objects are indicated, reflecting the prospective trends of their formation:

- The technological concept covers the use of innovative buildings and structures with the enrichment of the architectural environment with multimedia technologies; creating a dynamic structure of the building with the possibility of replacing its individual functional elements to increase the comfort of the architectural environment; and active modeling of architectural forms (projects in water, underground, and with other buildings);

- The environmental concept covers the desire to create and maintain a balance between architecture and the natural environment ("bio-tech" and "eco-tech" buildings), and a combination of technology and achievements of organic architecture and surrealistic sculptural building;

- The technological concept with an environmental focus covers the search for new forms of architectural space using innovative engineering technologies based on clean energy sources (transformation, change in functions, communication with the external environment);

- The anthropocentric concept strives for human domination: creating a model of the building of the future, changing the nature of human life (projects within the framework of the mobile building concept), and multiple redeployments of an architectural object with minimal time expenditure;

- The informational concept covers the desire to facilitate the processes of human life and streamline the structure of the house by introducing innovative automated technologies (projects based on the concept of intellectual objects of eco-oriented architecture).

Votinov, M, Smirnova, 0 


\section{References}

[1] Krizhanovskaya, N. Y. 2005: Osnovy landshaftnogo dizayna. Rostov-na-donu: "Feniks" (in Ukrainian)

[2] Wines, J. 2008: Green Architecture. London. Taschen

[3] Jodidio, P. 2009: Green architecture Now. Hong Kong, London, Paris, New York. Taschen

[4] Gossel, P.; Leuthauser, G. 2012: Architecture in the 20th Century. - Cologne. Taschen

[5] Broto, C. 2012: Small Houses in Nature. Links International

[6] Browning, D.; Gilmour, L. 2010: Living Architecture. NY. Assouline Publishing. Incorporated

[7] Zeiger, M. 2011: Micro Green: Tiny Houses in Nature. NY: Rizzoli International Publications. Incorporated

[8] Krizhanovskaya, N. Y.; Yankovich, S. S. 2007: Formirovaniye promezhutochnykh rekreatsionnykh prostranstv $\checkmark$ arkhitekturnoy srede. Uchebnoye posobiye, B. Uch-izd (in Ukrainian)

[9] Vergunov, A. P. 2008: Landshaftnaya arkhitektura: spetsializirovannyye ob'yekty. Uchebnoye posobiye dlya stud. VUZov., M.: ITS Akademiya (in Russian)

[10] Yigitcanlar, T. 2015: Smart cities: An effective urban development and management model?, Australian Planner, 52(1), pp. 27-34, https://doi.org/10.1080/07293682.2015.1019752

[11] Matreninskiy, S.; Mischenko, V.; Chertov, V. 2018: Formation of classes of urban environment areas for their renovation, MATEC Web of Conferences 193, 01014, https://doi.org/10.1051/matecconf/201819301014

[12] Dyda, I. A. 2009: Ekolohichni osnovy tradytsiynoyi ukrayins'koyi arkhitektury: monohrafiya. L'viv: Vydavnytstvo Natsional'noho universytetu "L'vivs'ka politekhnika" (in Ukrainian)

[13] Zvirgzdins, J.; Senfelde, M.; Plotka, K. 2018: Intellectual urban environment, New Challenges of Economic and Business Development - 2018: Productivity and Economic Growth. Riga, Latvia, pp. 815-824.

[14] Nefedov, V. A. 2012: Gorodskoy landshaftnyy dizayn. S-Pb. (in Russian)

[15] Cocchia, A. 2014: Smart and digital city: A systematic literature review. Smart City, Progress in IS, Springer, Cham, https://doi.org/10.1007/978-3-319-06160-3

[16] Proctor, R. 2009: 1000 New Eco Designs and where to find them. Laurence King c/o Chronicle Books

[17] https://www.toysforbigboys.com/orsos-luxury-island/, Accessed 15 January 2019

[18] http://nevsedoma.com.ua/index.php?newsid=109604, Accessed 15 January 2019

[19] Krizhanovskaya, N. Y.; Smirnova, O. V.; Degtev, I. A. 2013: Prirodointegrirovannyye individual'nyye zhilyye doma povyshennoy komfortnosti : monografiya. Belgorod: BGTU im. G. V. Shukhova (in Russian)

[20] Smirnova, O. V. 2016: Priyemy i etapy formirovaniya lendformennykh zdaniy $v$ gorodskoy srede. Naukoviy vísnik budívnitstva: Zb. nauk. pr. Kharkív: KHNUBA, 2 (84), pp. 82-86 (in Ukrainian)

[21] Smolyar, I. M.; Mikulina, Y. M.; Blagovidova, N. G. 2010: Ekologicheskiye osnovy arkhitekturnogo proyektirovaniya. Moskva: Akademiya (in Russian)

[22] https://dosug.md/ru/publication/1168/ , Accessed 15 January 2019

Please cite this article as:

Votinov, M.; Smirnova, O.: Eco-oriented architecture as a means of creating a sustainable urban environment, Electronic Journal of the Faculty of Civil Engineering Osijek-e-GFOS, 2019, 18, pp. 1-11, htps://doi.org/10.13167/2019.18.1 